\title{
Kontrol Kecepatan Putaran Permanent Magnet Synchronous Machine (PMSM) Menggunakan PID, FLC Dan ANFIS
}

\author{
Machrus Ali, Muhlasin \\ Teknik Elektro , Fakultas Teknik, Universitas Darul Ulum \\ Jalan Gus Dur 29A, Jombang \\ 0321-877157 \\ E-mail: machrus7@gmail.com, doktormuhlasin@gmail.com
}

\begin{abstract}
ABSTRAK
Permanent Magnet Syschronous Machine (PMSM) mempunyai torsi yang rendah dalam sejumlah aplikasi spesifik, sehingga diperlukan model kontrol yang baik. PMSM menggunakan prinsip percobaan faraday dengan memutar magnet dalam suatu kumparan dengan memanfaatkan sumber energi lain.. Saat magnet bergerak dalam suatu kumparan atau sebaliknya. Putaran mesin akan terjadi perubahan fluks gaya magnet dalam kumparan dan menembus tegak lurus terhadap kumparan sehingga timbul beda potensial antara ujung kumparan. Itu disebabkan adanya perubahan fluks magnetik. Untuk mendapatkan metode control yang paling baik, diperlukan perbandingan beberapa model control kecepatan. Dalam penelitian ini membandingkan control kecepatan PMSM tanpa kontroller, menggunakan PID kontroller, menggunakan FLC kontroller, dan menggunakan ANFIS kontroller. Dari hasil simulasi menunjukkan bahwa model terbaik pada ANFIS kontroller yaitu paling mendekati Speed reff (300 rpm) adalah ANFIS didapatkan profile putaran dengan undershot terkecil sebesar $300.015 \mathrm{rpm}$ pada saat $\mathrm{t}=0.0055$ detik dan steady state pada $300.02 \mathrm{rpm}$ pada 0.004 detik, didapatkan profile arus output terbaik pada FLC $=3.39$ A, sedang pada ANFIS = 3.38 A, didapatkan profile torsi terbaik (overshot terkecil) pada ANFIS controller sebesar $0.28 \mathrm{pu}$, didapatkan profile tegangan terbaik (paling kontinyu) pada ANFIS controller sebesar 300.03. Hasil penelitian ini akan dijanjutkan dengan penggunaan kecerdasan buatan lainnya.
\end{abstract}

Kata Kunci: Kontrol kecepatan, Anfis, flc, pid, permanent magnet synchronous machine

\section{PENDAHULUAN}

Synchronous Reluctance Machines

Synchronous reluctance Machines memanfaatkan desain rotor keengganan tetapi menggunakan belitan ac 3 fase standar. Sangkar induksi pada rotor memberikan torsi start, tetapi begitu mesin mendekati kecepatan sinkron, torsi keengganan akan menyinkronkan mesin dengan suplai. Mesin listrik yang secara dapat dioperasikan baik sebagai generator ataupun sebagai motor. Generator adalah salah satu mesin listrik yang bekerja berdasarkan energi gerak / mekanik yang kemudian mengubahnya menjadi energi listrik yang dapat dimanfaatkan dalam kehidupan sehari-hari. Fluks magnet dapat diubah dengan menggerakkan magnet di koil atau sebaliknya dengan memanfaatkan sumber energi lain, seperti angin dan air untuk memutar bilah turbin sehingga mereka menggerakkan magnet. Jika sebuah konduktor bergerak untuk memotong medan magnet akan ada perbedaan tegangan pada ujung konduktor(Djalal, Imran, Ali, \& Setiadi, 2017).

\section{PEMBAHASAN}

Meskipun Synchronous reluctance Machines memiliki torsi rendah, mereka dapat digunakan dalam sejumlah aplikasi spesifik(Morel, Rétif, Lin-Shi, \& Valentin, 2008), di mana kontrol kecepatan yang tepat diperlukan untuk memutar serat dengan ketebalan konstan. PMSM biasanya mesin tiga fase, meskipun banyak desain baru memiliki nomor fase lainnya(Chapman, 2002)(Budiman, Ali, \& Djalal, 2017)(Ali, 2012). Operasi pada dasarnya mirip dengan mesin sinkron medan-luka besar dengan satu pengecualian penting, PMSM biasanya dioperasikan dari elektronik tenaga variabel kecepatan dan tidak beroperasi pada kecepatan tetap tunggal. Proportional Integral Derivative (PID) Controller (H. Kusuma, Ali, \& Sutantra, 2017)(Arrohman, Fajardika, Muhlasin, \& Ali, 
2017), Fuzzi Logic Controller (FLC)(Raikhani, Ali, Ajiatmo, \& Budiman, 2016), dan Adaptive Neuro-Fuzzy Inference System (ANFIS)(Ali, Hunaini, \& Hartlambang, 2015) sering digunakan untuk mengatasi permasalah optimasi system. Kontroller tersebut telah banyak digunakan untuk menyelesaikan permasalahan optimasi kontrol motor(Hartlambang, Ali, \& Raikhani, 2015), optimasi turbin angin(Rachman, Muttaqin, \& Ali, 2017), optimasi wind diesel(Arrohman et al., 2017), optimasi mikrohidro(Kadaryono, Ali, Muhlasin, \& Budiman, 2016), optimasi photo voltaic(Octavian, Ari; Darmawan, Hofman; Nurohmah, Hidayatul; Ali, 2018)(Dripoyono, Henrdo; Candra, Dwi, Septa; Ajiatmo, Dwi;, Budiman, Budiman; Ali, 2018), optimasi steer kendaraan(Ali, Hunaini, Robandi, \& Sutantra, 2015)(D. H. Kusuma, Ali, \& Sutantra, 2017), rekonfigurasi jaringan listrik(Ali, Ajiatmo, \& Djalal, 2017)(Nurohmah, Raikhani, \& Ali, 2017), dan optimasi lainnya.

\section{PID Kontroller}

Proportional Integral Derivative Controller adalah controller suatu sistem instrumentasi dengan karakteristik adanya umpan balik pada sistem tersebut. Komponen PID terdiri dari 3 jenis konstanta, yaitu Proportional, Integratif, dan Derivatif. Ketiga konstanta dapat dipakai bersamaan maupun sendiri-sendiri, tergantung dari respon yang kita inginkan terhadap suatu plant.

PID adalah kontrol yang menggunakan komponen proportional, integratif, dan derivatif. Kontrol PID adalah sistem kontrol gabungan antara kontrol proporsional, integral, dan turunan (derivative). Pada metode ini, penalaan dilakukan dalam kalang tertutup dimana masukan referensi yang digunakan adalah fungsi tangga (step). Pengendali pada metode ini meliputi pengendali proporsional $(\mathrm{Kp})$, integral $(\mathrm{Ki})$, derivative $(\mathrm{Kd})$..

\section{Fuzzy Logic Controller (FLC)}

Pada penelitian kali ini digunakan metode fuzzy logic untuk memproses dan mengatur nilai masukkan referensi kecepatan yang telah di masukkan. Fuzzy logic controller menggunakan variabel linguistik bukan variabel numerik(Sivanandam, Sumathi, \& Deepa, 2007). Dalam sistem kontrol, kesalahan antara sinyal referensi dan sinyal output kesalahan sinyal dapat dijelaskan sebagai misalnya :

NB : Negative Big

NS : Negative Small
Z : Zero

PS : Positive Small

PB : Positive Big

Rule base yang akan digunakan di tunjukkan pada tabel kesalahan yang terdiri dari 5 anggota dan memiliki keluaran sebanyak 25 anggota.

Tabel 1 Rule Base Function

\begin{tabular}{|c|c|c|c|c|c|}
\hline e/de & NB & NS & Z & PS & PB \\
\hline NB & NB & NB & NB & NM & Z \\
\hline NS & NB & NM & NS & Z & PM \\
\hline Z & NB & NS & Z & PS & PB \\
\hline PS & NM & Z & PS & PM & PB \\
\hline PB & Z & PM & PB & PB & PB \\
\hline \multicolumn{5}{|c}{ Dalam software MATLAB simulink }
\end{tabular}

tersedia Fuzzy Logic Toolbox dimana memiliki 5 jenis Graphic User Interface (GUI) untuk merancang fuzzy inference system (FIS). Berikut merupakan 5 jenis Graphic User Interface (GUI):

1. Fis Editor

2. Membership function

3. Rule editor

4. Rule viewer

5. Surface viewer

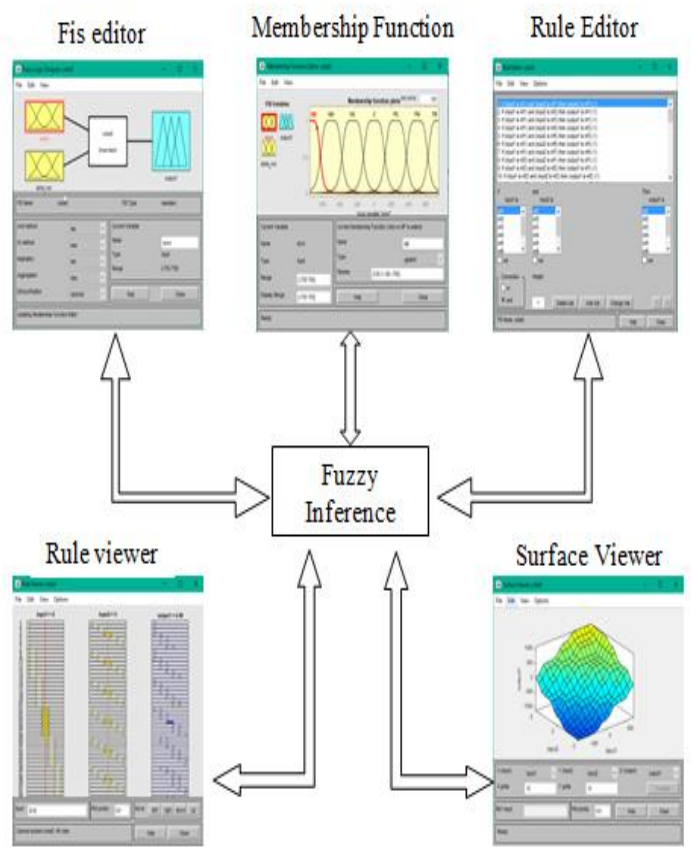

Gambar 1. Fuzzy Inference System pada Matlab 
Rule editor pada FLC dapat dilihat pada Gambar 2.

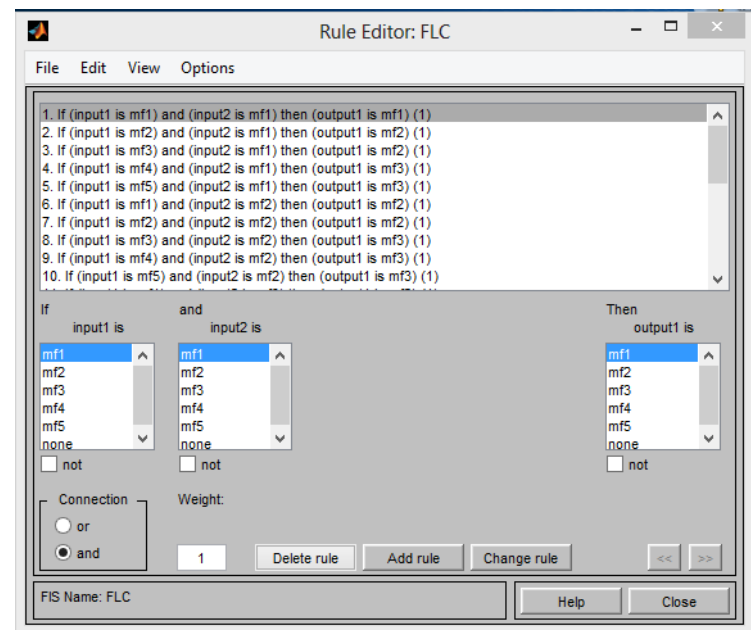

Gambar 2. Rule Editor FLC.

Rule Viewer FLC dapat dilihat pada Gambar 3.

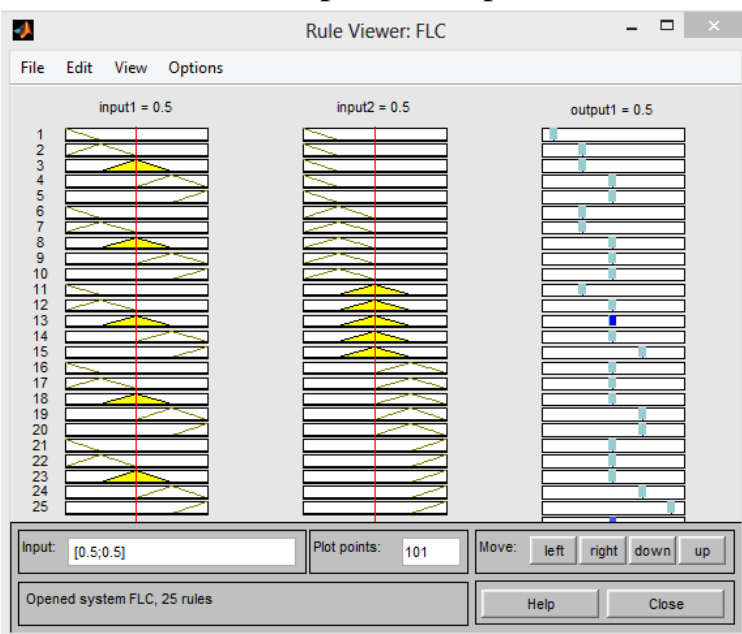

Gambar 3. Rule Viewer FLC

Surface Viewer FLC dapat dilihat pada Gambar 4.

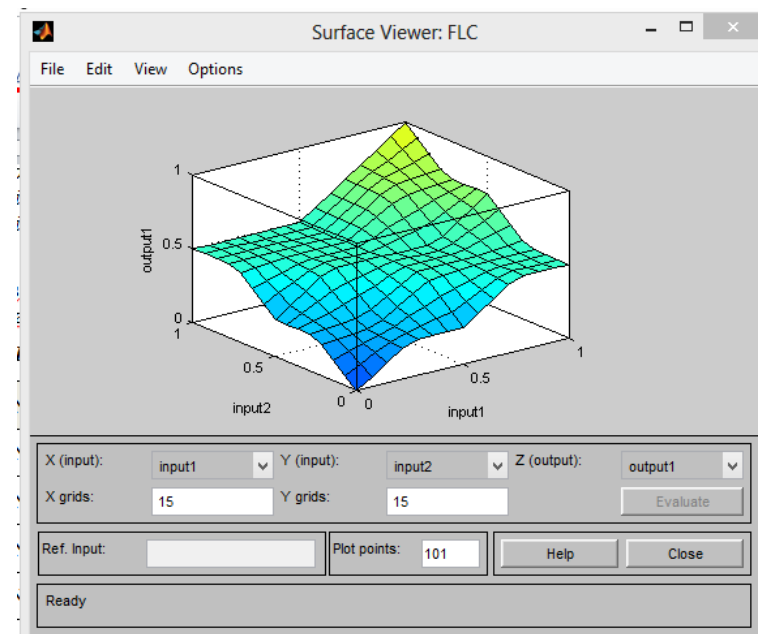

Gambar 4. Surface Viewer FLC

\section{Adaptive Neuro-Fuzzy Inference System}

Adaptive Neuro-Fuzzy Inference System (ANFIS) adalah penggabungan mekanisme Fuzzy Inference System (FIS) yang dijelaskan dalam arsitektur Neural Network (NN). Dalam simulasi, arsitektur ANFIS digunakan untuk memodelkan fungsi-fungsi nonlinier, mengidentifikasi komponen-komponen nonlinear secara online dalam sistem kontrol. Metodologi baru berdasarkan ANFIS untuk memperkirakan sudut pandang kendaraan. Ukuran tersebut telah divalidasi dengan membandingkan model CARSIM yang diusulkan, yang merupakan perangkat lunak yang divalidasi secara eksperimental(Jang, 1993). FIS yang digunakan adalah model fuzzy tingkat pertama dari model Tagaki-Sugeno-Kang (TSK) dengan pertimbangan kesederhanaan dan kemudahan komputasi.(Nafiardi, Rizqi; Fatkhur, Marsul; Muhlasin, Muhlasin; Askan, Askan; Ali, 2018) Urutan pertama mekanisme inferensi fuzzy TSK dengan dua input $x$ dan y (Gambar. 5). Rule base dengan dua aturan fuzzy if-then, seperti di bawah ini:

Rule 1 : if $\mathrm{x}$ is $\mathrm{A} 1$ and $\mathrm{y}$ is $\mathrm{B} 1$ then $\mathrm{f} 1=\mathrm{p} 1 \mathrm{x}$ $+\mathrm{q} 1 \mathrm{y}+\mathrm{r} 1$

Rule 2 : if $\mathrm{x}$ is $\mathrm{A} 2$ and $\mathrm{y}$ is $\mathrm{B} 2$ then $\mathrm{f} 2=\mathrm{p} 2 \mathrm{x}$ $+\mathrm{q} 2 \mathrm{y}+\mathrm{r} 2$

Input: $\mathrm{x}$ dan $\mathrm{y}$. konsekuen jika $\mathrm{f}$.

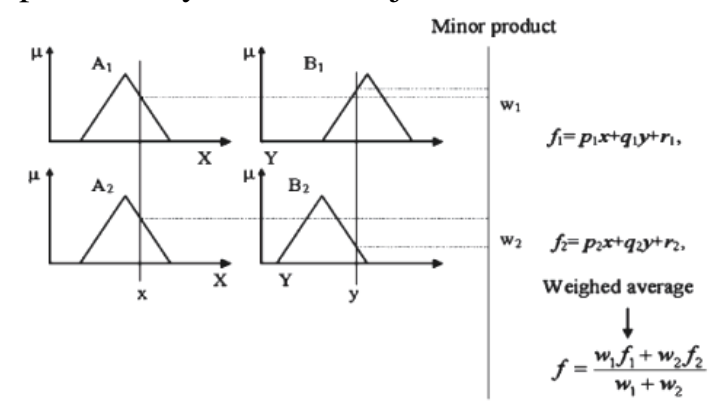

Gambar 5. Fuzzy inference system

Struktur ANFIS dapat dilihat pada Gambar 6.

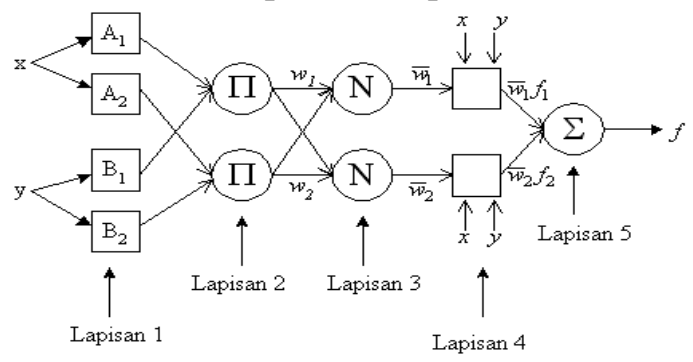

Gambar 6. Struktur ANFIS

Hasil training data ANFIS yang diambil dari data PID dapat dilihat pada Gambar 7. 


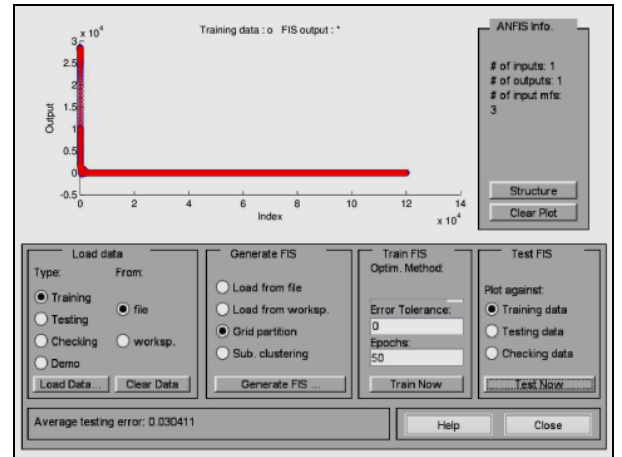

Gambar 7. Hasil training test data ANFIS

\section{Permanent Magnet Synchronous Machine}

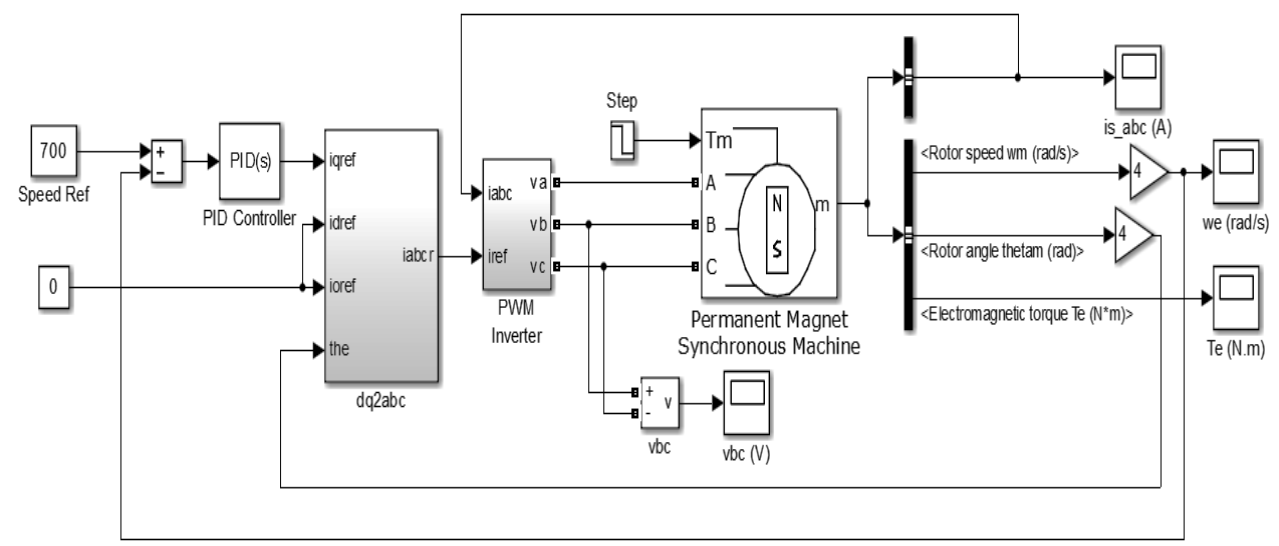

Gambar 5. Simulink MSM(Chapman, 2002)

Simulink konversi dq ke abc dapat dilihat pada Gambar 6.

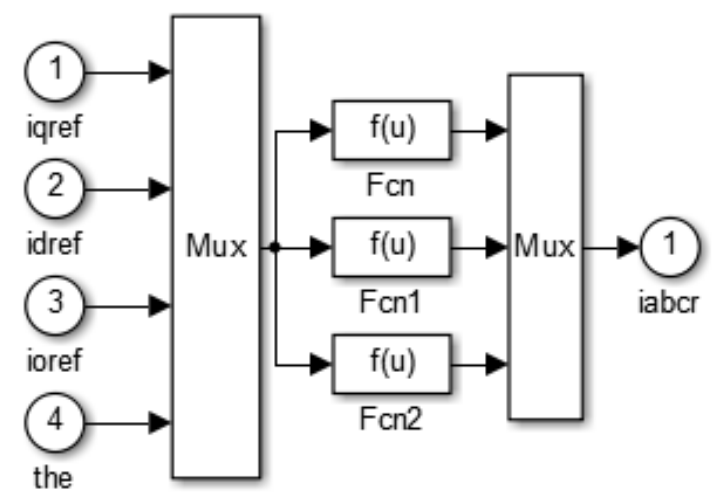

Gambar 6. Konversi sumbu dq ke abc

Gambar PWM inverter dapat dilihat pada Gambar 7.

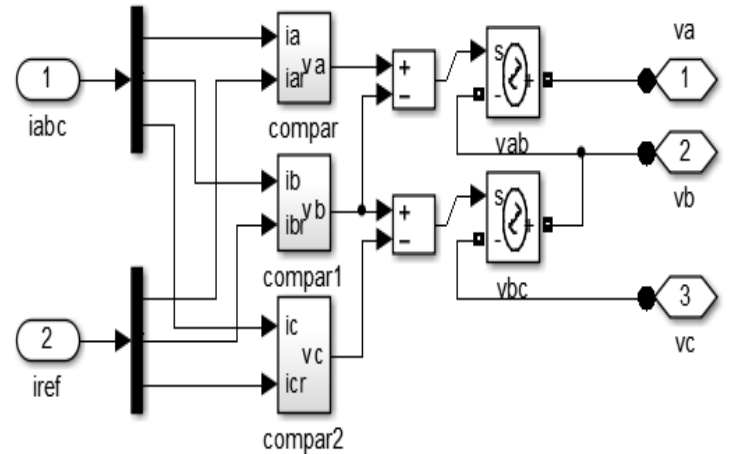

Gambar 7. PWM inverter

\section{Parameter Mesin}

Mesin tiga fase dengan nilai $1,1 \mathrm{~kW}, 300 \mathrm{~V}$, 300 rpm diumpankan oleh inverter PWM. Inverter PWM dibangun seluruhnya dengan blok Simulink® standar. Keluarannya melewati blok Sumber Tegangan Terkendali sebelum diterapkan pada belitan stator blok PMSM. Torsi beban yang diterapkan pada poros mesin pada awalnya diatur ke nilai nominalnya (3 $\mathrm{Nm}$ ) dan turun menjadi $1 \mathrm{Nm}$ pada $\mathrm{t}=0,04 \mathrm{dtk}$. 
Dua loop kontrol digunakan. Loop dalam mengatur arus stator motor. Lingkaran luar mengontrol kecepatan motor. Arus stator cukup "berippel" yang diharapkan ketika menggunakan inverter PWM. Juga, amplitudo arus ini berkurang pada $\mathrm{t}=0,04 \mathrm{~s}$, ketika beban berkurang. Rippel yang diperkenalkan oleh inverter PWM juga diamati dalam bentuk gelombang elektromagnetik torsi Te. Namun, inersia motor mencegah kebisingan ini muncul dalam bentuk gelombang kecepatan motor.

\section{Analisa Dan Pembahasan}

Desain PMSM dapat dilihat pada Gambar 8.

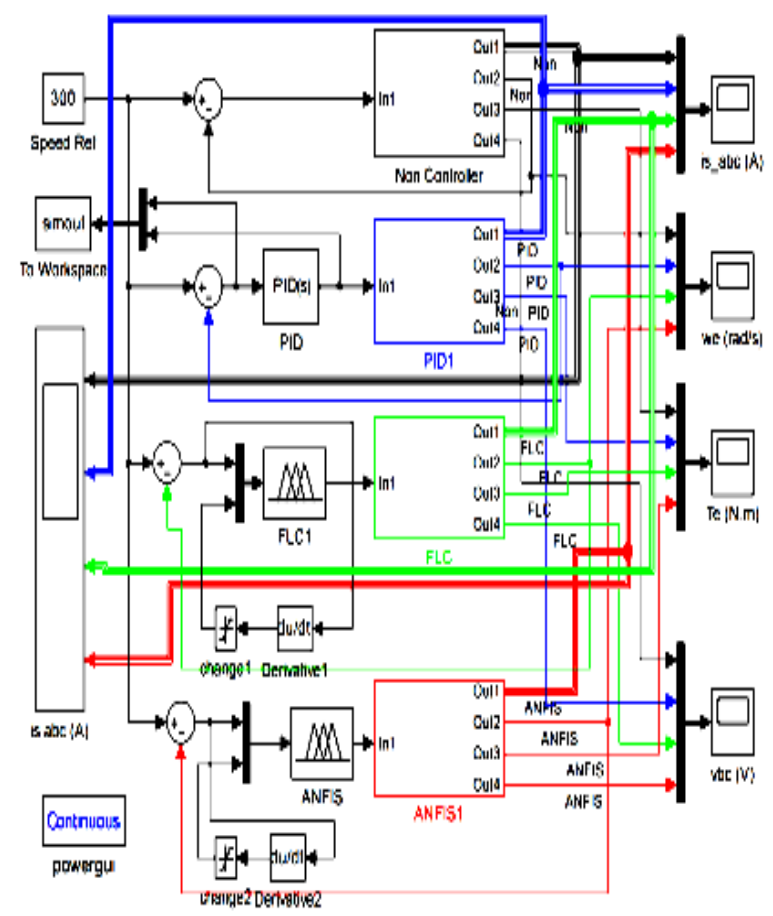

\section{Gambar 8. Desain model kontroller}

Profile arus output $\left(i_{\mathrm{s}}\right)$ dalam ampere, dapat dilihat pada gambar 9(a), 9(b), dan 9(c).
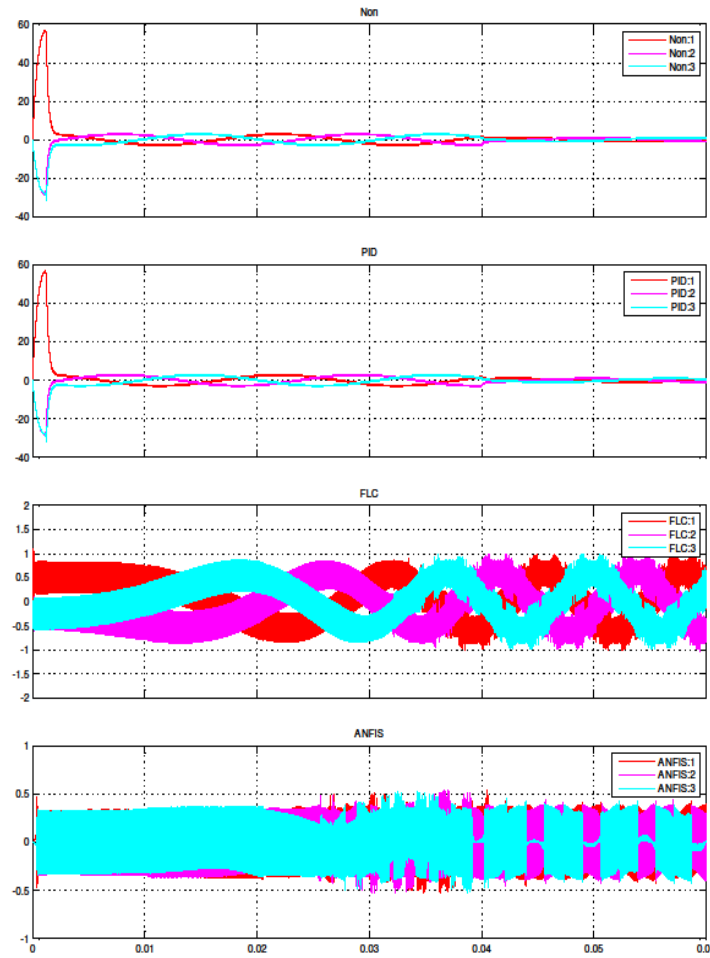

Time onssat 0

\section{9.(a)}
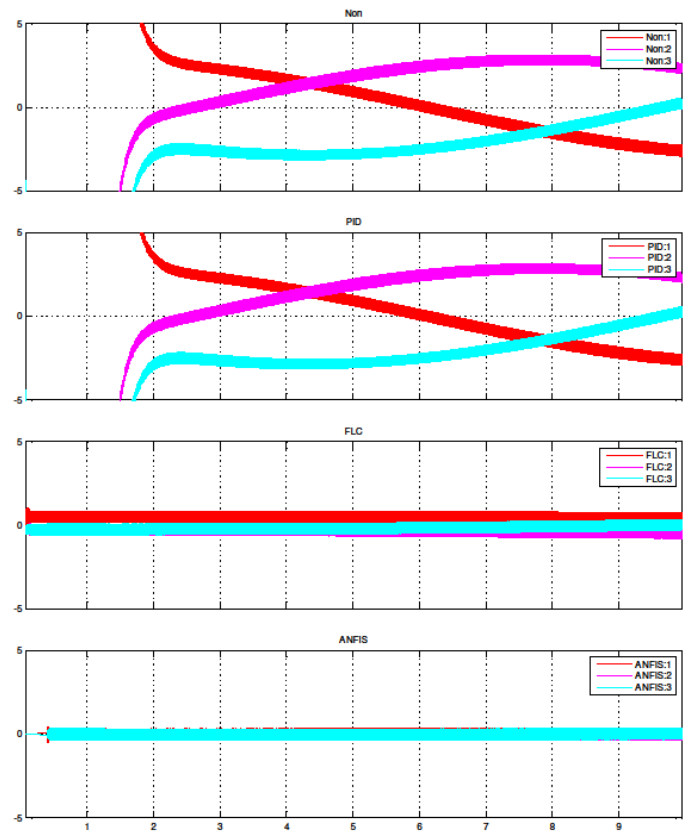

9.(b) 


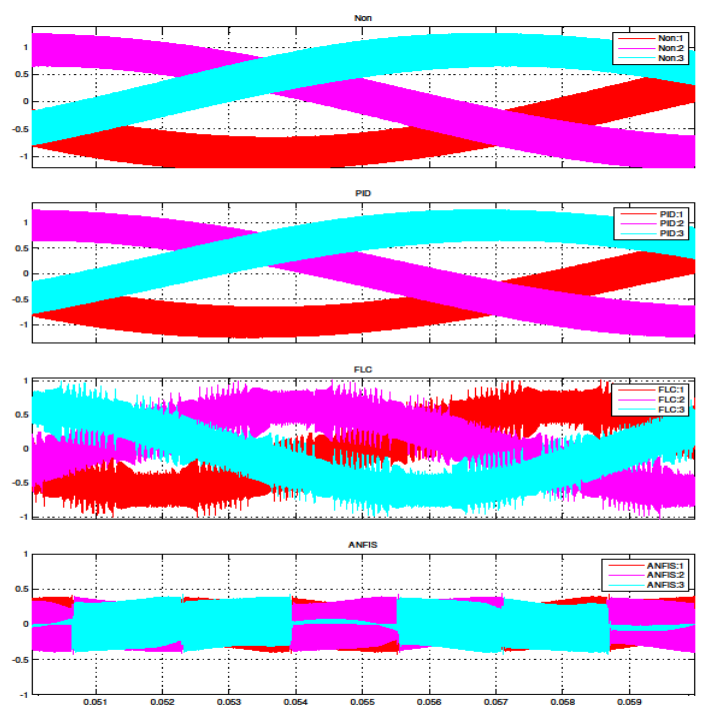

9. (c)

Gambar 9. Desain (a) Arus output 3 phasa, (b) Arus saat transien, (c) arus saat steady state

Dari gambar 9.(a), 9.(b), dan 9(c) menunjukkan bahwa profile arus outpun terbaik pada FLC controller. Pada saat transien dihasilkan overshot pada Tanpa Kontrol $=56.79 \mathrm{~A}$, pada $\mathrm{PID}=56.78$ A, pada $\mathrm{FLC}=15.26 \mathrm{~A}$, dan ANFIS $=16.85 \mathrm{~A}$. Pada steady state tanpa control $=0.98 \mathrm{~A}$, pada $\mathrm{PID}=0.99 \mathrm{~A}$, pada $\mathrm{FLC}=3.39 \mathrm{~A}$, dan pada ANFIS $=2.45 \mathrm{~A}$.

Profile Torsi yang didapatkan dapat dilihat pada gambar 10(a) dan 10(b)

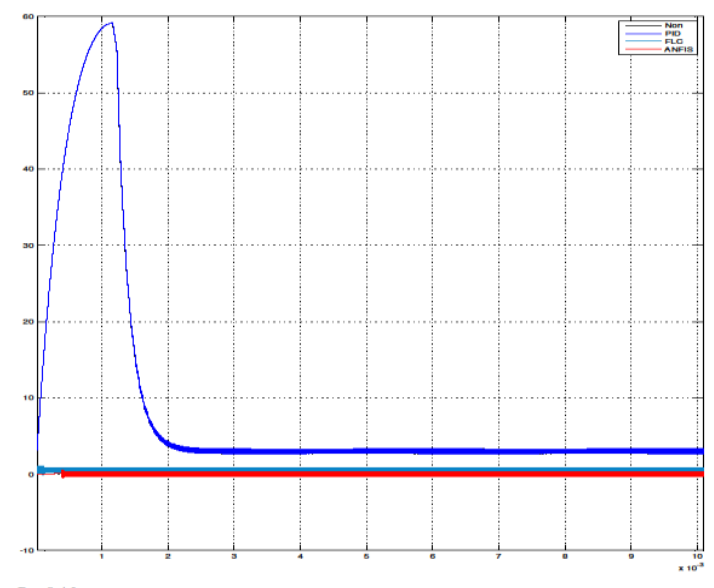

$0(a)$. profile saat transien

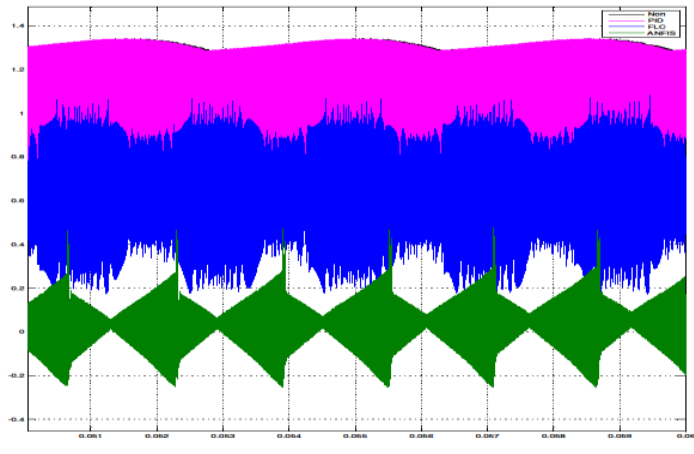

10 (b) saat steady state

Gambar 10. (a) Profile Torsi PMSM sat transien dan 10(b) profile torsi PMSM saat steady state.

Dari gambar 10.(a) dan 10.(b) menunjukkan bahwa profile torsi terbaik (overshot terkecil) pada ANFIS controller. Pada saat transien dihasilkan overshot pada Tanpa Kontrol $=59.19 \mathrm{pu}$, pada $\mathrm{PID}=59.19 \mathrm{pu}$, pada $\mathrm{FLC}=1.32 \mathrm{pu}$, dan ANFIS $=0.28 \mathrm{pu}$.

Profile Tegangan yang didapatkan dapat dilihat pada Gambar 11(a) dan 11(b).

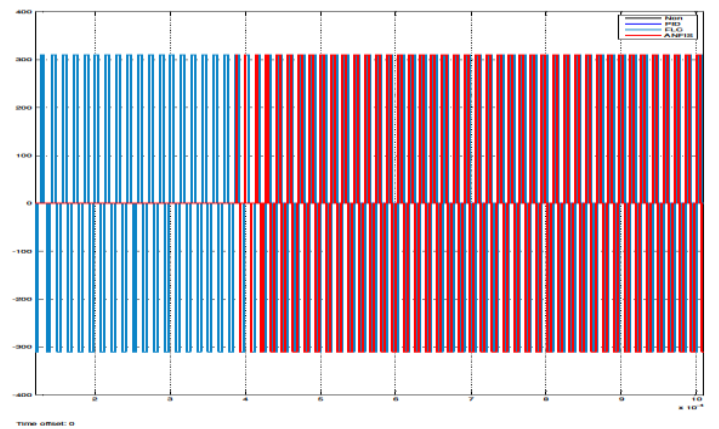

1(a). saat transien

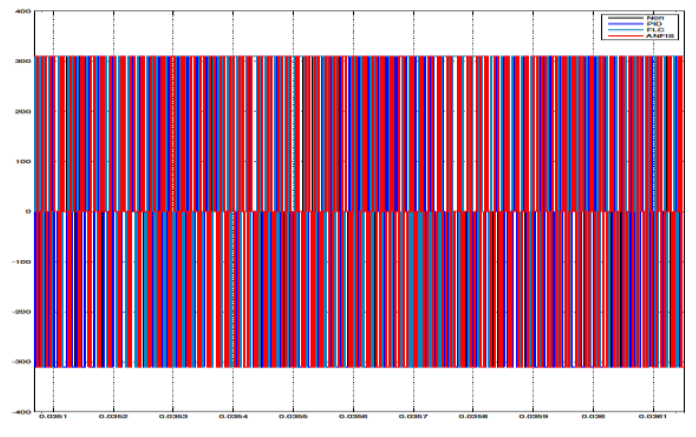

11(b) saat steady state

Gambar 11. (a) saat Transien, (b) saat steady state Profile tegangan PMSM 
Dari gambar 11.(a) dan 11.(b) menunjukkan bahwa profile tegangan terbaik (paling kontinyu) pada ANFIS controller. Pada saat transien dihasilkan frekuensi tegangan pada Tanpa Kontrol sebesar 296.8 Volt dengan frekuensi luaran $6.666 \mathrm{~Hz}$, pada PID sebesar 298.4 Volt dengan frekuensi luaran $8.33 \mathrm{kHz}$, pada FLC sebesar 300.2 Volt dengan frekuensi luaran $8.75 \mathrm{kHz}$, dan ANFIS sebesar 300.03 Volt dengan frekuensu luaran $8.84 \mathrm{kHz}$.

Gambar putaran mesin we (rad) bisa dilihat pada gambar 12.a dan 12.b .

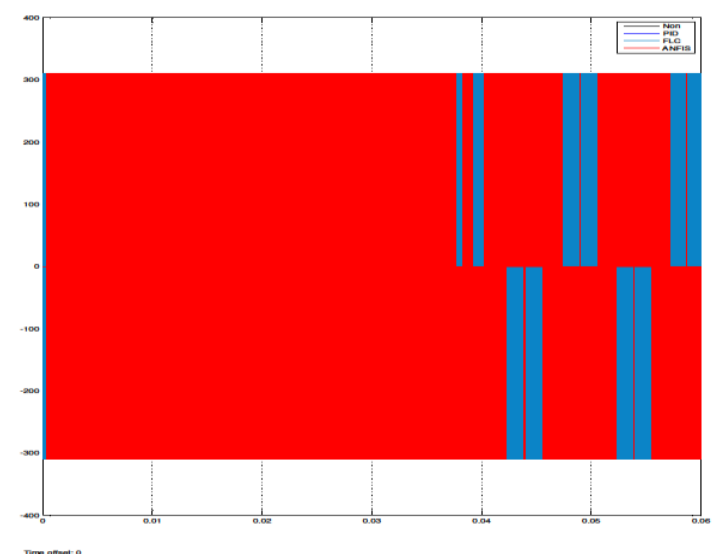

12.(a)

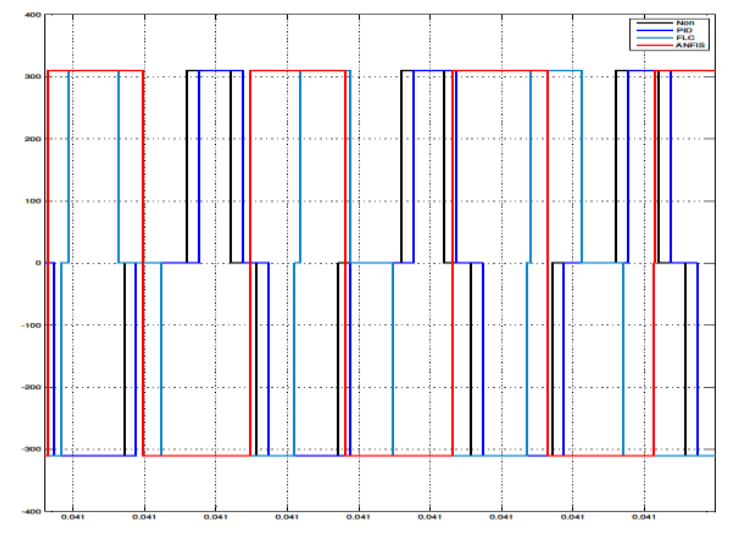

12.(b)

Gambar 12. (a). Gambar putaran mesin dalam radian (rad) dan (b). jika diperbesar (zoom)

Dari gambar 12.(a) dan 12.(b) menunjukkan bahwa model yang paling mendekati Speed reff (300 rpm) adalah ANFIS dengan undershot terkecil sebesar $300.015 \mathrm{rpm}$ pada saat $\mathrm{t}=0.0055$ detik dan steady state pada $300.02 \mathrm{rpm}$ pada 0.004 detik. Tanpa control terjadi undershot sebesar $297 \mathrm{rpm}$ pada saat $\mathrm{t}=0.0055$ detik dan steady state pada $299 \mathrm{rpm}$ pada 0.004 detik. PID control terjadi undershot sebesar $298.3 \mathrm{rpm}$ pada saat $\mathrm{t}=0.0055$ detik dan steady state pada $300.3 \mathrm{rpm}$ pada saat 0.04 detik. FLC terjadi undershot sebesar 0.002 pu pada saat $\mathrm{t}=0.0055$ detik dan steady state pada $300.3 \mathrm{rpm}$ pada saat 0.004 detik.

\section{KESIMPULAN}

Dari hasil simulasi menunjukkan bahwa model yang paling mendekati Speed reff $(300 \mathrm{rpm})$ adalah ANFIS didapatkan profile putaran dengan undershot terkecil sebesar $300.015 \mathrm{rpm}$ pada saat $\mathrm{t}=0.0055$ detik dan steady state pada 300.002 rpm pada 0.004 detik, didapatkan profile arus output terbaik pada FLC $=3.39$ A, didapatkan profile torsi terbaik (overshot terkecil) pada ANFIS controller sebesar $0.28 \mathrm{pu}$, didapatkan profile tegangan terbaik (paling kontinyu) sebesar 300.03 Volt dengan frekuensu luaran $8.84 \mathrm{kHz}$. Secara keseluruhan dapat dinyatakan bahwa desain control terbaik pada ANFIS controller.

\section{PUSTAKA}

Ali, M. (2012). Kontrol Kecepatan Motor DC Menggunakan PID Kontroler Yang Ditunning Dengan Firefly Algorithm. Intake: Jurnal Penelitian Ilmu Teknik Dan Terapan, 3(2), 1-10.

Ali, M., Ajiatmo, D., \& Djalal, M. R. (2017). Aplikasi Modified-ImperialistCompetitive-Algorithm (MICA) Untuk Merekonfigurasi Jaringan Radial Tenaga Listrik Pada Penyulang Mojoagung. JEEE$U$ (Journal of Electrical and Electronic Engineering-UMSIDA), 1(2), 49-53. https://doi.org/10.21070/jeee-u.v1i2.1020

Ali, M., Hunaini, F., \& Hartlambang, G. Y. (2015). Optimisasi Kontrol Kemudi Mobil Listrik Menggunakan Metode Adaptive Neuro-Fuzzy Inference System (ANFIS). Intake: Jurnal Penelitian Ilmu Teknik Dan Terapan, 6(2), 16-34.

Ali, M., Hunaini, F., Robandi, I., \& Sutantra, N. (2015). Optimization of active steering control on vehicle with steer by wire system using Imperialist Competitive Algorithm (ICA). In 2015 3rd International Conference on Information and Communication Technology (ICoICT) (pp. 500-503). IEEE. https://doi.org/10.1109/ICoICT.2015.7231 475

Arrohman, M., Fajardika, R., Muhlasin, \& Ali, M. (2017). Optimasi Frekuensi Kontrol pada Sistem Hybrid Wind-Diesel 
Menggunakan PID Kontroler Berbasis ACO dan MFA. In SAINTEK II-2017, UB, Malang (pp. 124-127).

Budiman, Ali, M., \& Djalal, M. R. (2017). Kontrol Motor Sinkron Permanen Magnet Menggunakan Algoritma Firefly. In SEMANTIKOM 2017, Universitas Madura (pp. 9-16). Retrieved from http://semantikom.unira.ac.id/2017/SEMA NTIKOM_2017_paper_3.pdf

Chapman, P. L. (2002). Permanent-Magnet Synchronous Machine Drives. Simulation. https://doi.org/10.1016/j.ecolmodel.2003.0 9.035

Djalal, M. R., Imran, A., Ali, M., \& Setiadi, H. (2017). Modifikasi Desain PID Controller Pada Permanent Magnet Synchronous Motor Dengan Flower Pollination Algorithm. Jurnal Teknik Elektro-ITP, 6(2), 163-169. Retrieved from https://ejournal.itp.ac.id/index.php/telektro/ article/view/652

Dripoyono, Henrdo; Candra, Dwi, Septa; Ajiatmo, Dwi; Budiman, Budiman; Ali, M. (2018). Penggunaan ACO dan FA Dalam Mengoptimalkanasikan Kontroler PID Untuk Shading Parsial pada Photovoltaic. SinarFe7, 1(1), 35-39. Retrieved from https://ejournal.fortei7.org/index.php/Sinar Fe7/article/view/27

Hartlambang, G. Y., Ali, M., \& Raikhani, A. (2015). Unjuk Kerja Kecerdasan Buatan (Artificial Intelligence) Dalam Mengoptimalkan Kecepatan Motor Dc Dengan Menggunakan Metode Imperalistt Competitive Alghorithm (ICA). Intake: Jurnal Penelitian Ilmu Teknik Dan Terapan, 6(1), 51-67. Retrieved from http://ejournal.undar.ac.id/index.php/intake /article/view/368

Jang, J. S. R. (1993). ANFIS: Adaptive-NetworkBased Fuzzy Inference System. IEEE Transactions on Systems, Man and Cybernetics, 23(3), 665-685. https://doi.org/10.1109/21.256541

Kadaryono, Ali, M., Muhlasin, \& Budiman. (2016). Desain Pengaturan Covernor Menggunakan Proportional Integral Derivative (PID) Pada Sistem Pembangkit Listrik Tenaga Mikro Hidro (PLTMH) Berbasis Particle Swarm Optimization (PSO). Intake: Jurnal Penelitian Ilmu Teknik Dan Terapan, 7(1), 40-54.
Retrieved from http://ejournal.undar.ac.id/index.php/intake /article/view/385

Kusuma, D. H., Ali, M., \& Sutantra, N. (2017). The comparison of optimization for active steering control on vehicle using PID controller based on artificial intelligence techniques. In Proceedings - 2016 International Seminar on Application of Technology for Information and Communication, ISEMANTIC 2016. Semarang: IEEE Conference. https://doi.org/10.1109/ISEMANTIC.2016. 7873803

Kusuma, H., Ali, M., \& Sutantra, N. (2017). The comparison of optimization for active steering control on vehicle using PID controller based on artificial intelligence techniques. In Proceedings - 2016 IEEEInternational Seminar on Application of Technology for Information and Communication, ISEMANTIC 2016. https://doi.org/10.1109/ISEMANTIC.2016. 7873803

Morel, F., Rétif, J. M., Lin-Shi, X., \& Valentin, C. (2008). Permanent magnet synchronous machine hybrid torque control. IEEE Transactions on Industrial Electronics, 55(2), 501-511. https://doi.org/10.1109/TIE.2007.911938

Nafiardi, Rizqi; Fatkhur, Marsul; Muhlasin, Muhlasin; Askan, Askan; Ali, M. (2018). Optimasi Kontroller CES dan ANFIS Untuk Meredam Osilasi Frekuensi Pada Mikrohidro Berbasis Ant Colony Optimization. SinarFe7, l(1), 46-51. Retrieved from https://ejournal.fortei7.org/index.php/Sinar Fe7/article/view/30

Nurohmah, H., Raikhani, A., \& Ali, M. (2017). Rekonfigurasi Jaringan Distribusi Radial Menggunakan Modified Firefly Algorithms (MFA) Pada Penyulang Tanjung Rayon Jombang. JEEE-U (Journal of Electrical and Electronic Engineering-UMSIDA), $1(2), \quad 13$. https://doi.org/10.21070/jeee-u.v1i2.1064

Octavian, Ari; Darmawan, Hofman; Nurohmah, Hidayatul; Ali, M. (2018). Optimasi Dual Axis Tracking Untuk Photovoltaic Berbasis Firefly Algorithm dan Ant Colony Optimization. SinarFe7, 1(1), 177182. Retrieved from https://ejournal.fortei7.org/index.php/Sinar 
Fe7/article/view/59

Rachman, M. F., Muttaqin, S., \& Ali, M. (2017). Penggunaan Metode Imperialist Competitive Algorithm (ICA) untuk kontrol Frekuensi pada Wind-Turbine dan Hybrid Wind-Diesel. In SAINTEK II-2017, UB, Malang (pp. 99-102). Malang: Universitas Brawijaya, Malang.

Raikhani, A., Ali, M., Ajiatmo, D., \& Budiman. (2016). Desain Optimal Automatic Voltage Regulator Pada Pembangkit Listrik Mikro Hidro Menggunakan Fuzzy Logic Controller. Intake: Jurnal Penelitian Ilmu Teknik Dan Terapan, 7(1), 30-39. Retrieved from http://ejournal.undar.ac.id/index.php/intake /article/view/384

Sivanandam, S. N., Sumathi, S., \& Deepa, S. N. (2007). Introduction to fuzzy logic using MATLAB. Introduction to Fuzzy Logic using MATLAB. https://doi.org/10.1007/978-3-540-35781-0 
JE-Unisla, Vol 4 No 1 Maret 2019 | 